\title{
Stocking rate effects on goats: A research observation
}

\author{
MIGUEL MELLADO, RAUL VALDEZ, LAURA M. LARA, AND RAMIRO LOPEZ
}

Authors are Professor of Reproductive physiology, Graduate Student, Research Biologist, and Professor of Ruminant nutrition, Department of Nutrition and Feeds, Universidad Autónoma Agraria Antonio Narro, Saltillo, México.

\begin{abstract}
Knowledge on the ecological effects of goat grazing on arid rangeland is far from complete, and specifically there is little scientific information on effects of heavy goat grazing on arid ecosystems. One objective of this study was to determine botanical composition of dairy-type goat diets on heavily ( 1.5 ha per goat) and lightly (15 ha per goat) grazed Chihuahuan desert range by fecal microhistological analysis. A second objective was to determine whether vegetation cover, some blood metabolites and mineral levels, as well as fertility of goats were sensitive to high grazing pressure. The lightly grazed site had more $(\mathrm{P}<$ $0.05)$ total foliage cover $(38.6$ vs $30.4 \%)$ than the overstocked pasture. Total shrubs in diets of goats was greater $(86.4 \mathrm{vs} 72.4$ in the late-dry period, 78.6 vs 42.1 in late-wet period; $P<0.05$ ) on the heavily stocked pasture than the lightly stocked pasture. Forbs in the diets were lower $(P<0.10)$ in the late-dry $(11.4$ vs $21.5 \%)$, early-wet (55.4 vs 64.0\%) and late-wet period (15.0 vs $45.8 \%$ ) on the heavily stocked pasture than the lightly stocked pasture. Substantially lower $(P<0.01)$ serum glucose, urea nitrogen, $\mathrm{Zn}$ and Mg concentration at the onset of the breeding period in goats on the heavily stocked pasture, compared to goats on the lightly grazed pasture resulted in a higher $(P<0.01)$ abortion rate $(22$ vs $12 \%)$ and consequently a lower $(P<0.05)$ kidding rate $(42$ vs $55 \%)$. We concluded that overstocking with goats greatly reduced shrub and grass cover. Also, decades of continuously high grazing pressure has forced goats to alter diet selection pattern by consuming more resinous, toxic, and coarse species. This switch was associated with a lower nutritional status, a negative daily weight gain, lower body condition score in the late-wet period, and lower fertility on heavily grazed range.
\end{abstract}

Key Words: Diets, blood chemistry, fertility, vegetation cover, Chihuahuan desert

In arid and semi-arid zones of Mexico, goats are managed under traditional extensive village systems and are grazed on natural communal range throughout the year with no supplements. Thus, the typical goat production system involves concentration of several large herds of goats in the communities and often surpasses the carrying capacity of these rangelands. The result is a severely overgrazed range in poor condition. An increase in stocking pressure generally represents a decrease in quantity and/or quality of forage available to the grazing animals. Few studies have described the relation between goat stocking and diet composition. Studies with Angora goats have shown that although average annual diets were similar on lightly and heavily

\footnotetext{
Financial support was received from World Wildlife Foundation (Project PN59). Manuscript accepted 27 May 02.
}

\section{Resumen}

El impacto ecológico del pastoreo de las cabras en los agostaderos áridos continua siendo un tema de debate, y todavía no existe suficiente información científica sobre el impacto del pastoreo de las cabras sobre ecosistemas áridos. Mediante la técnica microhistológica se estudió la composición botánica de la dieta de cabras mestizas lecheras mantenidas en agostaderos con alta ( 1.5 ha por cabra) y baja (15 ha por cabra) presión de pastoreo, en un matorral parvifolio inerme. También se determinó el efecto de la carga animal sobre la cobertura vegetal, niveles de metabolitos y minerales en la sangre y la fertilidad de las cabras. El sitio con baja densidad de cabras presentó mayor $(P<0.05)$ cobertura de vegetación $(38.6$ vs $30.4 \%)$. El porcentaje de arbustos fue mayor (86.4 vs 72.4 al final del periodo de sequía, 78.6 vs 42.1 al final del periodo lluvioso; $P<0.05$ ) en la dieta de las cabras en el terreno con sobrepastoreo, comparado con el terreno de baja densidad de cabras. El contenido de herbáceas fue menor $(P<0.10)$ en la dieta de las cabras en el terreno con sobrepastoreo en comparación con el sito con baja densidad de cabras al final del período de sequía. Niveles más bajos ( $P<0.01)$ de glucosa, urea, $\mathrm{Zn}$ y Mg en el suero sanguíneo en las cabras en el terreno con alta presión de pastoreo, en comparación con el terreno con baja carga animal resultó en un mayor $(P<0.01)$ porcentaje de abortos $(22$ vs $12 \%)$, y un menor $(P<\mathbf{0 . 0 5})$ porcentaje de pariciones (42 vs 55\%). Se concluyó que una alta presión de pastoreo ha incrementado la utilización por las cabras de plantas resinosas, tóxicas y fibrosas. Este cambio se refleja en un estatus nutricional más bajo, lo cual conduce a pérdidas de peso y condición corporal en el otoño, lo cual a su vez provoca una menor fertilidad de las cabras.

grazed ranges, periodic differences in dietary botanical composition resulted from the 2 grazing treatments (Malechek and Leinweber 1972). Owens (1991) indicated that as goat density increased, utilization in the $0.75-1.5 \mathrm{~m}$ zone of Acacia shrubs community increased at a faster rate than in any other canopy zones. Provenza and Malechek (1984) found that goats showed preference for basal twigs of blackbrush in heavily stocked pastures, whereas no preference for terminal or basal twigs was observed in lightly and moderately stocked pastures. Knowledge of dairy-type goat diets under different stocking pressures remains incomplete, therefore the objective of the study was to describe forage selection and botanical composition of goat diets and relate disparities to stocking pressure. An additional aim of this study was to examine whether blood chemistry and fertility of goats and vegetation cover were sensitive to stocking level. 


\section{Materials and Methods}

\section{Study Area}

The study was conducted on a 2,250 and 1,050 ha site associated with 2 adjacent rural communities $(2 \mathrm{~km}$ apart, with a fence dividing the sites) in northeast Mexico $\left(25^{\circ} 30^{\prime} \mathrm{N}, 101^{\circ} 02 \mathrm{~W}\right)$. The communities had similar types of vegetation, soil, terrain and precipitation and were selected based on different grazing pressure of goats and the absence of other stock. Vegetation cover was 8 percentage points higher in the lightly stocked pasture. The rainy season extends from June to October with mean annual precipitation being $326 \mathrm{~mm}$. Mean elevation of the study area is $1,700 \mathrm{~m}$ and average annual temperature is $18.2^{\circ} \mathrm{C}$. Soils in the study site were silty and depth overlaying a limestone substrate ranged from 250 to $650 \mathrm{~mm}$. The plant community was dominated by creosotebush (Larrea tridentata (DC.) Cov.). Other important browse species were resin-bush (Viguiera greggii (Gray) Blake) and lechuguilla (Agave lechuguilla Torr.). Major grasses were blue grama (Bouteloua gracilis H.B.K.) and buffalo grass (Buchloe dactyloides (Nutt) Engelm). Major forbs were globemallow (Sphaeralcea angustifolia (Cav.) D. Don.), silver-leaf nightshade (Solanum elaeagnifolium Cav.) and rosval (Croton dioicus Cav.).

\section{Goat characteristics and manage- ment}

Two flocks of goats $(n=163$ and 167 for high and low stocking rate, respectively) were used in this study. Goats were of undefined genotype (milk-type) of different ages and parity with 35 to $45 \mathrm{~kg}$ adult live weight. All animals were reared in the same areas where they were tested, had no health intervention, and did not receive feed or mineral supplements throughout the year.

In and around settlements, land use is predominantly by goats, which are managed under a traditional extensive village system and are grazed on natural communal range throughout the year. The grazing period is approximately 8 hours daily (from 1000 to 1800 hours) and animals are tended by herdsmen. Goats are penned near the household at night without access to feed and water.

The lightly grazed area had been grazed continuously by goats at the rate of 15 ha per goat for several decades (one 150-herd goat in 2,250 ha). In the heavily grazed area the annual stocking rate averaged 1.5 ha per goat ( 5 different flocks totaling 700 animals in $1050 \mathrm{ha}$ ), and this grazing pres- sure has been maintained for several decades.

All does of both herds were exposed to crossbred (milk-type) bucks (3\% bucks per herd) during 4 weeks in January 2000. Body condition score (5-point scale; Santucci and Maestrini 1985) were recorded at mating. Abortions and kiddings were also recorded.

In January 2000 , blood samples $(5 \mathrm{ml})$ from all adult goats in both flocks ( $\mathrm{n}=$ 330) were collected from the jugular vein (vacutainer system), in the morning before grazing (14-16 hours from the last feeding). The blood samples were obtained in non-heparinized vacutainer tubes. Within 2 hours of collection the samples were centrifuged at $3,000 \mathrm{~g}$ for 15 minutes at room temperature. Serum was collected and stored at $-20^{\circ} \mathrm{C}$ until analyzed for cholesterol, glucose, creatinine, urea, uric acid, total proteins, calcium, phosphorus, copper, magnesium and zinc. All blood metabolites analyses were carried out with a Coleman Junior II spectrophotometer following protocols supplied by the kit manufacturer. All minerals, except phosphorus, were determined by atomic absorption spectrophotometry. Phosphorus was determined by the method of Fiske and Subbarow (1925).

Thirty randomly selected adult lactating goats of each herd were weighed twice in the fall 1999 (22 October and 16 December). Animals were weighed after feed and water were withheld overnight.

$$
\text { Selection value }=\frac{(\% \text { in diet }-\% \text { cover of total vegetation })}{(\% \text { in diet }+\% \text { cover of total vegetation })} \times 10
$$

\section{Botanical composition of the vegeta- tion}

Vegetation sampling was carried out just before the start of feces sample collections for each of the 3 seasonal periods. Five transects, $500 \mathrm{~m}$ in length, were established in sites frequently grazed by goats in both the lightly and heavily grazed areas. Transects were positioned to avoid watering points and roads. Vegetation (foliage) cover data were collected along these transects in the late-dry (April), early-wet (July) and late-wet seasons (November) of 2000. The line-intercept method (Canfield 1942) was used to determine percent cover. In each transect the intercept of each plant species was summed and divided by the total length of the transect to obtain the percent cover per sampling unit (transect).
Fecal samples collection and analysis

Feces samples were collected from the rectum of 6 randomly-selected adult goats during 5 consecutive days in late-dry (spring), early-wet (summer) and late-wet (fall) periods. The same goats were used in each collection period. Samples were pooled across days within periods for each animal. The samples were oven-dried and ground through a 1-mm screen. Small subsamples were taken from the ground material and mounted in microscopic slides. Five slides from each sample were analyzed. Composition of goat diets was determined by counting the number of epidermal fragments of each species recognized in 100 microscope fields at $125 \mathrm{x}$ (Sparks and Malechek 1968). Some authors recommend the use of correction factors for forbs when the microhistological analysis is used, due to higher digestibility of forbs compared to grasses (Holechek et al. 1982) and their more fragile epidermal layers (Bartolome et al. 1995). However, other authors dismiss the use of correction factors on the grounds that phenological variation in digestibility is often more significant than taxonomic variation (Hansen et al. 1976). In this study correction factors for forbs were not used.

Selection values for individual plants were calculated as the ratio of each class percentage in the diet to its percentage availability (percentage cover) in the range (Taylor et al. 1980). The formula used in developing these ratings was:

An index value of 0 indicated nonselective use of a forage class; values $>0$ or $<0$ indicated grazing selectivity for or against a particular species, respectively. Similarity of diets was calculated using Kulczyniski's similarity index (Oosting 1956).

\section{Statistical analyses}

T-tests were used to compare shrub, forbs, grass and total vegetation cover between pastures within seasons (Steel and Torrie 1980). The numbers of epidermal fragments of each species were converted to percentages and transformed to arcsin (angular) prior to statistical analysis. For each individual species as well as life forms, $\mathrm{t}$-tests at $\mathrm{P}<0.10$ were used to compare goat diets between pastures within seasons. Significant differences in selection indices were assessed using the 


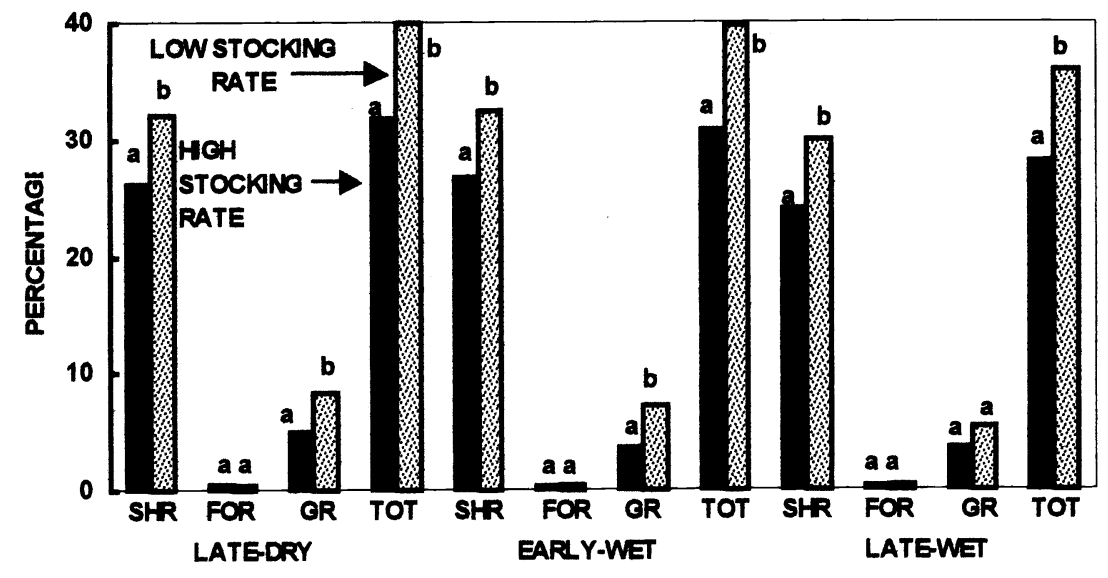

Fig. 1. Shrubs (SHR), forbs (FOR), grasses (GR) and total (TOT) vegetation cover for lightly and heavily stocked ranges in the Chihuahuan desert for 3 seasons. Paired bars with different letters differ $(P<0.05)$ between ranges within each sampling period.

Kruskal-Wallis test (SAS 1990). Differences in serum metabolites and minerals as well as body weight change between localities were assessed using the t-test procedure (Steel and Torrie 1980). Percentage of aborting does and proportion of does pregnant was compared using chisquare procedures (Steel and Torrie 1980). Statistical significance was assumed at $\mathrm{P}<$ $0.05)$. Finally, these findings depict unreplicated research (only one flock from each site) and results should be applied to other areas with some trepidation.

\section{Results and Discussion}

\section{Vegetation cover}

The lightly grazed site had significantly $(\mathrm{P}<0.05)$ more shrub cover throughout the year than the heavily stocked pasture (Fig. 1). Because the study site was not accessible to other domestic ungulates and shrubs were generally palatable to goats, it is thought that the marked decrease of shrubs, particularly creosotebush (136\% decrease cover of this shrub in the heavily grazed pasture compared to the lightly grazed pasture) on the pasture heavily grazed, arose from intensive goat grazing. This finding is consistent with that of Manzano and Navar (2000) on the reduced cover of shrubs as a result of goat overgrazing. For most of the year the grass cover was less $(\mathrm{P}<0.05)$ on the heavily grazed compared to the lightly grazed site. Although it is known that non-Angora goats make limited use of grasses in this type of vegetation (Mellado et. al. 1991), the decrease of graminoids in the heavily grazed site was also likely due to high grazing pressure. Forb cover was very low in both sites and remained nearly the same on the two treatments. Major forbs in the study site were short-lived and dynamics were largely controlled by rainfall, rather than by grazing. In common with other studies in arid environments (Severson and Debano 1991) forbs did not increase in response to decreasing shrub cover in the heavily grazed pasture. In terms of management these results indicate that goat production would be favoured by conservative continuous grazing in this type of vegetation.

\section{Botanical composition of diets}

At the 3 seasons sampled the number of species detected in the goat diet were 34 vs 28,30 vs 24 , and 34 vs 29 on heavily and lightly grazed areas in the late-dry, early-wet and late-wet periods, respectively. The contribution of shrubs to the diet was greater $(\mathrm{P}<0.05)$ on the heavily grazed range than the lightly grazed range in the late-dry and late-wet periods (Table 1 ). The predominance of shrubs (above $80 \%$ ) in diets during the dry season on similar types of vegetation is consistent with Mellado et al. (1991). They found diets contained up to $93 \%$ shrubs on an overgrazed Larrea-dominated range. Higher dietary shrub content in goat diets in both the heavily and lightly stocked sites in the late-dry period was a function of decreased cover of grasses and forbs in this period. High stocking rates resulted in increased $(\mathrm{P}<0.05)$ utilization of creosotebush by goats in the late-dry and latewet periods. Goats on the lightly stocked site tended to avoid or consume only minor amounts of creosotebush, but goats on the heavily grazed area relied heavily on this shrub. This was a surprising finding; as it was expected that goats would not be able to cope with the chemical defenses in creosotebush. The heavy use of this resinous shrub by goats was of interest because creosotebush is generally considered unimportant and undesirable livestock forage. These results are contrary to other reports where creosote bush has been a minor diet component of Angora (Warren et al. 1984a) and Spanish goats (Mellado et al. 1991, Warren et al. 1984b). These results reaffirm that goats can live on forages rich in secondary metabolites and lignin (Provenza et al. 1990).

The relatively high consumption of poisonous plants (e.g. creosotebush, Asclepias brachystephana Torr. and silver-leaf nightshade) by goats on the heavily stocked range merits discussion. The tolerance for high levels of poisonous plants in goat diets probably was due to the utilization of the less-toxic portion of these plants (ruminants possess the ability to select plant parts of low toxin concentrations; Provenza 1995, Pfister 1999). However, observations on the heavily stocked pasture showed that creosotebush was uniformly and intensively used, to the point that the bark of these plants was consumed. Another explanation is that goats may have the ability to detoxify some plant poisons. Studies with desert woodrats (Mangione et al. 2000) pigmy rabbits (White et al. 1982) and goats (Duncan et al. 2000) have documented the development of mechanisms to adapt to plant secondary metabolites.

Under the heavy grazing intensity, goats consumed agrito (Berberis trifoliolata Moric.) and Spanish dagger (Yucca carnerosana (Trel.) Mckelvey), whereas in the lightly grazed area these species were not used. The high consumption of fibrous, resinous and poisonous plants by goats on the heavily stocked range reaffirm the notion that goats are very flexible with respect to the plants they consume.

Another shrub of singular importance was mesquite (Prosopis glandulosa Torr.), which contributed $7.8 \%$ to total composition of the diets of goats in the heavily stocked site in the late-dry period. In the late-wet period a significant grazing intensity effect $(\mathrm{P}<0.05)$ was detected in the percentage of this shrub in the goat diets. The level of mesquite in the goat diets in the present study is much higher than that reported in other studies (Lopez-Trujillo and García-Elizondo 1995; Mellado et al. 1991). Goats on both ranges made consis- 
Table 1. Percentage of shrubs, forbs and grasses in goats' diets on heavily and lightly stocked ranges.

\begin{tabular}{|c|c|c|c|c|c|c|}
\hline \multirow{2}{*}{$\begin{array}{l}\text { Species } \\
\text { Shrubs }\end{array}$} & \multicolumn{2}{|c|}{$\begin{array}{c}\text { Late-dry } \\
\text { Stocking rate }\end{array}$} & \multicolumn{2}{|c|}{$\begin{array}{c}\text { Early-wet } \\
\text { Stocking rate }\end{array}$} & \multicolumn{2}{|c|}{$\begin{array}{c}\text { Late-wet } \\
\text { Stocking rate }\end{array}$} \\
\hline & High & Low & High & Low & High & Low \\
\hline Acacia farnesiana & 4.6 & 3.1 & 5.6 & 3.2 & 8.6 & 4.1 \\
\hline Agave lechuguilla & 2.3 & 6.3 & 0.0 & 0.0 & 3.2 & 0.0 \\
\hline Agave striata & $0.6+$ & 3.3 & 0.0 & 0.7 & 1.0 & 0.0 \\
\hline Atriplex canescens & 9.8 & 5.3 & 0.0 & 1.5 & 4.3 & 2.0 \\
\hline Berberis trifoliolata & 1.6 & 0.0 & 3.0 & 0.0 & 2.7 & 2.5 \\
\hline Buddleja scordioides & $1.1+$ & 5.7 & 4.8 & 7.2 & $1.1^{* *}$ & 16.3 \\
\hline Condalia warnockii & 4.3 & 2.0 & 0.7 & 1.0 & 0.0 & 0.0 \\
\hline Cowania plicata & 5.8 & 2.3 & 1.4 & 3.0 & $9.7 *$ & 0.5 \\
\hline Dalea bicolor & 3.4 & 1.5 & 3.0 & 0.0 & $4.0^{*}$ & 0.2 \\
\hline Dasylirion palmeri & $1.2^{*}$ & 6.3 & 1.2 & 0.7 & 2.6 & 1.7 \\
\hline Ephedra aspera & 2.0 & 2.6 & 0.2 & 0.0 & 1.2 & 1.5 \\
\hline Larrea tridentata & 15.3 & 7.6 & $6.4^{* *}$ & 1.2 & $11.3 * *$ & 1.5 \\
\hline Opuntia leptocaulis & $0.4 *$ & 3.0 & 0.0 & 0.0 & 1.6 & 1.0 \\
\hline Opuntia rastrera & 6.8 & 4.8 & 1.4 & 1.9 & 1.4 & 1.9 \\
\hline Parthenium incanum & $7.9^{* *}$ & 13.6 & 4.1 & 4.4 & $13.9 * *$ & 1.2 \\
\hline Prosopis glandulosa & 7.8 & 4.0 & 0.3 & 0.3 & $5.0^{*}$ & 2.1 \\
\hline Yucca carnerosana & 5.9 & 0.0 & 0.0 . & 0.0 & 3.2 & 0.0 \\
\hline Other shrubs & 5.6 & 1.0 & 3.0 & 2.5 & 3.8 & 5.6 \\
\hline Total shrubs & $86.4^{*}$ & 72.4 & 35.1 & 27.6 & $78.6 * *$ & 42.1 \\
\hline \multicolumn{7}{|l|}{ Forbs } \\
\hline Asclepias brachystephana & 4.2 & 0.0 & & & 0.2 & 0.0 \\
\hline Sida abutifolia & 0.9 & 1.6 & 4.8 & 0.0 & 0.0 & 5.2 \\
\hline Solanum elaeagnifolium & $2.6^{*}$ & 6.9 & 18.1 & 18.4 & $5.1^{*}$ & 17.0 \\
\hline Sphaeralcea angustifolia & $1.5^{* *}$ & 9.7 & 27.6 & 36 & $6.8^{* *}$ & 22.1 \\
\hline Other forbs & 2.2 & 3.3 & 4.9 & 9.6 & 3.1 & 1.5 \\
\hline Total forbs & $11.4+$ & 21.5 & $55.4+$ & 64.0 & $15.0^{* *}$ & 45.8 \\
\hline \multicolumn{7}{|l|}{ Grasses } \\
\hline Aristida arizonica & 1.2 & 0.8 & $0.7+$ & 3.1 & $0.5^{*}$ & 2.4 \\
\hline Bouteloua curtipendula & 0.2 & 0.7 & 2.4 & 3.8 & 1.8 & 1.9 \\
\hline Bouteloua gracilis & 0.3 & 1.8 & 2.2 & 0.2 & 2.0 & 2.6 \\
\hline Other grasses & 0.4 & 2.8 & 4.2 & 1.3 & 2.1 & 5.2 \\
\hline Total grasses & $2.1+$ & 6.1 & 9.5 & 8.4 & 6.4 & 12.1 \\
\hline
\end{tabular}

$+\mathrm{p}=<0.10 ; \mathrm{p}=<0.05 ; * * \mathrm{p}=<0.01$ for comparisons between stocking rates within periods.

tent use of huizache (Acacia farnesiana (L.) Willd.) during all periods. Use of this shrub as well as mesquite by goats was somewhat limited because animals could not reach the higher canopies. Butterflybush (Buddleja scordioides H.B.K.) was significantly more important in goat diets on the lightly grazed area in the late-dry and late-wet period, compared to goats on the heavily grazed area.

Differences $(P<0.10)$ occurred in total forbs in goat diets on the heavily and lightly grazed areas during the late-dry and late-wet seasons (Table 1). Ralphs et al. (1986) also found that forbs declined in sheep diets as the stocking rate increased.

Major forbs in the goat diets in the heavily and lightly stocked ranges included silver-leaf nightshade and globe-mallow. These forbs were consistently higher $(\mathrm{P}<$ 0.05 ) in diets of goats on the low stocked range compared to that of heavily stocked range. Of the nearly 30 species represented in goat diets in the heavy and lightly stocked sites at the beginning of the rainy season, globe-mallow constituted one third of the diets. The abundance of forbs in the diets is explained by the fact that actively growing forbs in the Chihuahuan desert have higher protein, phosphorous, and cell soluble materials than grasses during active growth (Nelson et al. 1970).

A forb of singular importance was milkweed (Asclepias brachystephana Torr.), a poisonous plant which made up $4.2 \%$ of the diet during the late-dry period on the heavily stocked range, but was not present in diets on the lightly grazed site.

There were no differences in percentages of grasses in diets between stocking levels in summer and fall, but a trend $(\mathrm{P}<$ 0.08 ) was noted indicating a higher proportion of grasses in goat diets on the low stocked range in the late-dry period. Arizona three-awn (Aristida arizonica Vasey.) was significantly $(\mathrm{P}<0.07)$ more important in diets on the lightly grazed range than the heavily stocked site in the early-wet and late-wet periods. Under the heavy grazing intensity the grass compo- nent was reduced in the late-dry period causing more dependence on shrubs.

Regardless of stocking level, utilization of grasses by goats in our study was low, which agrees with Lopez-Trujillo and Garcia-Elizondo (1995) and Mellado et al. (1991) in the same type of vegetation. Other Chihuahuan desert studies have shown much higher proportions of grasses in Spanish goat diets. Warren et al. (1984a) reported that grasses contributed over half of the diets during spring, but $17 \%$ in autumn. Warren et al. (1984b) found grass utilization by Spanish goats was between 17 and $68 \%$.

In the Chihuahuan desert rangelands it is reported that high grazing pressure has little effect on diet selection by Angora goats (Malechek and Leinweber 1972, Taylor and Kothmann 1990). It is believed that the outstanding foraging skills of goats (upper mobile lip, bipedal grazing stance and prehensile tongue) allows selection of preferred forages even at excessive grazing pressure. Our data with milk-type goats do not support such a contention because high grazing pressure forced goats to have a more flexible foraging strategy.

Illius et al. (1999) indicated that goats select diets which tend to maximize their rate of intake, rather than expressing preferences that are specific to plant species. Moreover, hunger (Grote and Brown 1973) and social facilitation (Ralphs and Provenza 1999) rapidly extinguish food aversion. Thus, the different diet strategy showed by goats on the site with high grazing pressure apparently was an adaptation (behavioiral and physiological) to the condition imposed by grazing pressure. In other trials (Baptista and Launchbaugh 2001; Warren et al 1984b) a considerable variation between individuals with respect to voluntary consumption of unpalatable species has been found, therefore the flock on the overstocked site possibly developed an enhanced detoxification or tolerance ability. If this is true, goats with these capabilities could constitute a management strategy to increase the use of plants containing deterrents or toxicants.

\section{Dietary preferences}

The influence of stocking level on dietary selection values is shown in Table 2 . In general, goats on the heavily stocked site were less selective (proportions of forage species in their diets more closely matched the proportions available), than goats on the lightly stocked range, regardless of period of the year.

Among shrubs, huizache, fourwing saltbush (Atriplex canescens (Pursh) Nut.), 
Table 2. Selection values for shrubs, forbs and grasses of goats on heavily and lightly stocked ranges.

\begin{tabular}{|c|c|c|c|c|c|c|}
\hline \multirow{2}{*}{$\begin{array}{l}\text { Species } \\
\text { Shrubs }\end{array}$} & \multicolumn{2}{|c|}{$\begin{array}{c}\text { Late-dry } \\
\text { Stocking rate }\end{array}$} & \multicolumn{2}{|c|}{$\begin{array}{c}\text { Early-wet } \\
\text { Stocking rate }\end{array}$} & \multicolumn{2}{|c|}{$\begin{array}{c}\text { Late-wet } \\
\text { Stocking rate }\end{array}$} \\
\hline & High & Low & High & Low & High & Low \\
\hline Acacia farnesiana & 9.7 & 9.5 & $8.5^{*}$ & 9.5 & 8.4 & 9.3 \\
\hline Agave lechuguilla & $-4.6^{* *}$ & 5.8 & & & 2.1 & \\
\hline Agave striata & $-2.8^{* *}$ & 4.1 & & 2.4 & 9.5 & \\
\hline Atriplex canescens & 8.9 & 9.1 & & 8.2 & 9.5 & 9.3 \\
\hline Berberis trifoliolata & 4.9 & & 8.4 & & 7.9 & 9.6 \\
\hline Buddleja scordioides & 8.8 & 9.0 & 9.4 & 8.5 & 9.1 & 9.6 \\
\hline Condalia warnockii & 7.7 & 8.2 & & & & \\
\hline Cowania plicata & $8.2^{*}$ & 6.5 & $3.2 *$ & 6.0 & $8.4^{* *}$ & 3.1 \\
\hline Dalea bicolor & 8.7 & 7.1 & 8.1 & & 8.8 & 6.2 \\
\hline Dasylirion palmeri & $8.4^{*}$ & 9.1 & 7.6 & 9.5 & 6.4 & 7.3 \\
\hline Ephedra aspera & $4.3^{* *}$ & 9.0 & -5.1 & & 6.2 & 7.9 \\
\hline Larrea tridentata & -4.6 & -7.7 & $-8.5^{*}$ & -9.6 & $-5.9 * *$ & -9.3 \\
\hline Opuntia leptocaulis & $2.1^{*}$ & 4.3 & & & $2.7^{*}$ & -2.6 \\
\hline Opuntia rastrera & 8.6 & 9.4 & $4.0^{* *}$ & 9.5 & $4.0^{* *}$ & 9.9 \\
\hline Parthenium incanum & 8.3 & 9.3 & 9.1 & 8.8 & $9.8 * *$ & 6.1 \\
\hline Prosopis glandulosa & $9.2^{*}$ & 6.4 & $1.9 *$ & -3.3 & $7.9 *$ & 4.6 \\
\hline Yucca carnerosana & 0.4 & & & & -0.2 & \\
\hline \multicolumn{7}{|l|}{ Forbs } \\
\hline Asclepias brachystephana & 8.7 & & & & 5.5 & \\
\hline Sida abutifolia & 7.5 & 8.6 & 8.9 & & & 8.4 \\
\hline Solanum elaeagnifolium & 8.0 & 9.2 & 8.9 & 9.2 & $8.4^{*}$ & 9.6 \\
\hline Sphaeralcea angustifolia & 8.0 & 9.2 & $7.1 * *$ & 8.6 & $5.0^{* *}$ & 8.7 \\
\hline \multicolumn{7}{|l|}{ Grasses } \\
\hline Aristida arizonica & $6.4+$ & 3.7 & 7.7 & 5.6 & $2.3^{* *}$ & 5.9 \\
\hline Bouteloua curtipendula & -1.3 & 2.3 & $3.2 *$ & 6.7 & 1.7 & 0.4 \\
\hline Bouteloua gracilis & -2.0 & -0.6 & $7.3 *$ & 3.4 & 1.2 & -1.3 \\
\hline
\end{tabular}

$+\mathrm{p}=<0.10 ;{ }^{*} \mathrm{p}=<0.05 ;{ }^{*} \mathrm{p}=<0.01$ for comparisons between stocking rates within periods.

butterfly-bush, Condalia warnockii M.C. Johnst, Cowania plicata D. Don., Dalea bicolor H. \& B. and mariola (Parthenium incanum H.B.K.) in both treatments and in the different seasons were eaten in proportions much higher than their relative availability would suggest. In both the heavily and lightly stocked sites creosotebush was utilized less than expected during the 3 seasons, although during the early-wet and late-wet seasons this shrub was significantly $(\mathrm{P}<0.05)$ less preferred by goats on the lightly stocked site. Despite the avoidance shown for creosotebush, this shrub still made an important contribution to diets on the lightly grazed area.

Goats on the heavily stocked pasture showed a consistently higher $(\mathrm{P}<0.05)$ preference for mesquite compared to goats on the lightly stocked site. Because mesquite causes conditioned flavor aversion in ruminants (Baptista and Launchbaugh 2001), it is likely that the intake of mesquite exhibited by goats on the heavily stocking pasture was not a true reflection of animal preference, but a product of forced utilization caused by a shortage of browse. The relatively high use of this shrub provoked intoxication in several goats. Signs of intoxication were mandibular tremors and uncontrolled chewing, which resulted in the death of all affected animals ( 7 out of 163 adult goats). These clinical signs from mesquite ingestion are caused by a selective toxicity to neurons of some cranial nerve nuclei (Tabosa et al. 2000).

Less selective grazing by goats on the heavily stock site was probably due to depletion of accessible foliage of favored species which forced the goats to turn to other less palatable choices. Walker et al. (1994) have shown that as vegetation was progressively defoliated, goats were less selective. Additionally, our goats were restricted overnight to a pen and only able to forage for 8 hours each day. This restricted foraging time probably also caused the goats to favor some of the less palatable species.

Forbs were highly preferred on both ranges, notably after summer rains. Of note, milkweed and silver-leaf nightshade, species considered toxic for livestock, were highly preferred by goats in both treatments. Forbs had higher selection values than grasses and shrubs, indicating they would have selected more forbs had they been available.
Goats in both the heavily and lightly stocked pastures showed a moderate preference for Arizona three-awn, but all others grasses were consumed in proportion to availability. The marked differences in selectivity in the lightly and heavily stocked ranges stress the fact that preferences can not be generalized because selection depends on the available choice of feed items.

Diet similarities between the heavily and lightly grazed ranges were 99,72 , and $40 \%$ for the late-dry, early-wet, and late-wet periods, respectively. The high similarity indices in the late-dry period were expected because warm-season species had not yet begun rapid growth and the least amount of forage was available. With higher forage availability (late-wet period) the similarity index was low, reflecting the effect of stocking density. Low overlap during wet times occurred when goats on the lightly stocked site concentrated more on forbs than goats on the heavily stocked site.

\section{Blood chemistry and reproductive performance}

The effect of stocking level on average daily gain, body condition score (BCS), reproductive performance and blood chemistry is presented in Table 3 . A significant stocking level effect was detected for average daily gain and BCS in the latewet season. The weight loss and lower BCS for goats on the heavily stocked site indicate a lack of nutrients in this pasture. The substantially higher $(P<0.01)$ serum glucose levels in goats on the lightly grazed area compared to the heavily grazed site is additional evidence of shortage of forage in the heavily stocked site. Glucose is a relatively good indicator of energy balance, decreasing as goats are subjected to energy restriction (Hussain et al. 1996) or fed lower levels of concentrate supplementation (Landau et al. 1993).

Serum urea nitrogen was substantially higher $(P<0.01)$ in goats on the lightly grazed area than in the heavily grazed site. This metabolite originates either from catabolism of amino acids to spare glucose oxidation, or from ammonia absorbed by the rumen (Oldham 1984). Thus, high urea levels could indicate undernutrition, reflecting increased gluconeogenesis from amino acids, or high protein intake. In this study the higher serum urea levels in goats on the lightly stocked site is believed to be due to a higher protein intake. Serum creatinine levels were lower $(\mathrm{P}<0.01)$ in these animals, than goats on the heavily stocked site, and this metabolite is an indi- 
Table 3. Daily gain, body condition score, reproductive performance and blood chemistry of goats on heavily $(n=167)$ and lightly $(n=163)$ stocked ranges. Values following \pm are standard error of the mean.

\begin{tabular}{lcc}
\hline \hline Item & High stocking rate & Low stocking rate \\
\hline Reproductive traits & $22(37 / 167)^{* *}$ & $12(20 / 163)$ \\
Abortion $(\%)$ & $42(74 / 167)^{*}$ & $55(90 / 163)$ \\
Percentage kidding & $60(101 / 167)$ & $67(110 / 163)$ \\
Does pregnant $(\%)$ & $4.2(7 / 167)$ & $0(0 / 163)$ \\
Mortality due to toxic plants $(\%)$ & \\
Blood chemistry & & $64.0 \pm 1.1$ \\
Glucose $(\mathrm{mg} / 100 \mathrm{ml})$ & $48.9 \pm 1.3^{* *}$ & $12.1 \pm 0.29$ \\
Urea $(\mathrm{mg} / 100 \mathrm{ml})$ & $10.8 \pm 0.33^{* *}$ & $0.60 \pm .04$ \\
Creatinine $(\mathrm{mg} / 100 \mathrm{ml})$ & $0.73 \pm .05^{* *}$ & $72 \pm 2.2$ \\
Cholesterol $(\mathrm{mg} / 100 \mathrm{ml})$ & $66 \pm 3.2+$ & $6.8 \pm .06$ \\
Total proteins $(\mathrm{g} / 100 \mathrm{ml})$ & $6.5 \pm .13$ & $11.0 \pm .08$ \\
Calcium $(\mathrm{mg} / 100 \mathrm{ml})$ & $11.2 \pm .16$ & $1.4 \pm .09$ \\
Phosphorus $(\mathrm{mg} / 100 \mathrm{ml})$ & $4.0 \pm .11+$ & $2.08 \pm 0.06$ \\
Copper $(\mathrm{ppm})$ & $1.79 \pm 0.06$ & $2.33 \pm 0.05$ \\
Magnesium $(\mathrm{ppm})$ & $1.93 \pm 0.06^{* *}$ & \\
Zinc (ppm) & $1.66 \pm 0.05^{* *}$ & $2.7 \pm 0.04$ \\
Body traits & & $11 \pm 3.7$ \\
Body condition score $(0-5$ scale) & $2.1 \pm 0.04^{* *}$ & \\
Average daily gain $(\mathrm{g} / \mathrm{d})$ & $-19 \pm 2.3^{* *}$ & \\
\hline
\end{tabular}

$+\mathrm{p}=<0.10 ;{ }^{*} \mathrm{p}=<0.05 ; * * \mathrm{p}=<0.01$

cator of muscle break down.

A trend $(\mathrm{P}<0.07)$ was noted for higher serum cholesterol levels in goats on the lightly stocked site than in goats on the heavily stocked range. This metabolite, in the absence of excess dietary energy intake, is considered to reflect the capacity of the animal to mobilize body fat reserves (Ingraham and Kappel 1988). This suggests that during winter, goats on the lightly stocked site catabolized more fat reserves than goats on the heavily stocked site.

Serum phosphorus tended $(\mathrm{P}<0.10)$ to be higher in goats on the lightly grazed area than heavily stocked site. Both serum $\mathrm{Zn}$ and $\mathrm{Mg}$ were significantly higher $(\mathrm{P}<$ 0.01 ) in goats on the lightly stocked site compared to goats in the heavily stocked site.

Percent of pregnant does was not significantly affected by stocking rate, but goats on the heavily stocked pasture had higher $(\mathrm{P}<0.01)$ abortion rates and consequently lower $(\mathrm{P}<0.05)$ kidding rates. Of the possible mechanisms inducing non-infectious abortions in the goats, the hypoglycemic condition in the mother (Wentzel 1982) was the most likely cause of gestation failure. Mean serum glucose of goats on the lightly stocked site was $31 \%$ higher than goats on the heavily stocked site. Serum $\mathrm{Mg}$ levels as low as ours have been associated with massive abortions in goats (Mellado et al. 2002, Unanian and Feliciano-Silva 1984).
Bartolome, J., J. Franch, M. Gutman, and N.G. Seligman. 1995. Physical factors that influence fecal analysis estimates of herbivore diets. J. Range Manage. 48:267-270.

Canfield, R.H. 1942. Application of the line interception method of sampling range vegetation. J. Forest. 39:388-394.

Duncan, A.J., P. Frutos, and S.A. Young. 2000. The effect of rumen adaptation to oxalic acid on selection of oxalic-acid rich plants by goats. British J. Nutr. 83:59-65.

Fiske, C.H. and Y. Subbarow. 1925. The colorimetric determination of phosphorus. J. Biol. Chem. 66:371-375.

Grote, F.W. Jr. and R.T. Brown. 1973. Deprivation level affects extinction of conditioned taste aversion. Learn. Motiv. 4:314-319.

Hansen, R.M., T.M. Foppe, M.B. Gilbert, R.C. Clark, and H.W. Reynolds. 1976. The microhistological analysis of feces as an estimator of herbivore diets. Unpublished report, AAFAB Composition Analysis Laboratory, Inc., Ft. Collins, Colo.

Holechek, J.L., M. Vavra, and R.D. Pieper. 1982. Botanical composition determination of range herbivore diets: a review. J. Range Manage. 35:309-315.

Hussain, Q., O. Harevoll, L.O. Eik, and E. Ropstadt. 1996. Effect of energy intake on plasma glucose, non-sterified fatty acids and aceto-acetate concentration in pregnant goats. Small Rumin. Res. 21:89-96.

Illius, A.W., I.J. Gordon, D.A. Elston, and J.D. Milne. 1999. Diet selection in goats: a test of intake-rate maximization. Ecol. 80:1008-1018.

Ingraham, R.H., and L.C. Kappel. 1988. Metabolic profile testing. Vet. Clin. North America: Food Anim. Prac. 4:391-411.

Landau, S., J. Vecht, and A. Perevolotsky. 1993. Effects of two level of concentrate supplementation on milk production of dairy goats browsing Mediterranean shrubland. Small Rumin. Res. 11:227-237.

Lopez-Trujillo, R. and R. Garcia-Elizondo. 1995. Botanical composition and diet quality of goats grazing natural and grass reseeded shrublands. Small Rumin. Res. 16:37-47.

Malechek, J.C. and C.L. Leinweber. 1972. Forage selectivity by goats on lightly and heavily grazed ranges. J. Range Manage. 25:105-111.

Mangione, A.M., M.D. Dearing, and W.H. Karasov. 2000. Interpopulation differences in tolerance to creosote bush resin in desert woodrats (Neotoma lepida). Ecol. 81:2067-2076.

Manzano, M.G. and J. Navar. 2000. Processes of desertification by goats overgrazing in the Tamaulipan thornscrub (matorral) in north-eastern Mexico. J. Arid Env. 44:1-17.

Mellado, M., R.H. Foote, A. Rodríguez, and P. Zarate. 1991. Botanical composition and nutrient content of diets selected by goats grazing on desert grassland in northern Mexico. Small Rumin. Res. 6:141-150. 
Mellado, M., R. Valdez, L.M. Lara, and J.E. Garcia. 2002. Risk factors for conception, abortion, and kidding rates of goats under extensive conditions. Small Rumin. Res. (In press)

Nelson, A.B., C.H. Herbel, and H.M. Jackson. 1970. Chemical composition of forage species selected by cattle on an arid New Mexico Range. New Mexico Agr. Exp. Bull, 561.

Oldham, J.D. 1984. Protein-energy interrelationships in dairy cows. J. Dairy Sci. 67:1090-1114.

Oosting, H.J. 1956. The study of plant communities. W.H. Freeman \& Co. San Francisco, Calif.

Owens, M.K. 1991. Utilization patterns by Angora goats within the plant canopies of two Acacia shrubs. J. Range Manage. 44:456-461.

Pfister, J.A. 1999. Behavioral strategies for coping with poisonous plants. P 45-59. 1999. In: K.L. Launchbaugh, K.D. Sanders, and J.C. Mosley. (eds) Grazing behavior of livestock and wildlife. Idaho Forest, Wildlife, and Range Exp. Sta. Bull. No. 70. Moscow, Ida.

Provenza, F.D. 1995. Postingestive feedback as an elementary determinant of food preference and intake in ruminants. J. Range Manage. 48:2-17

Provenza, F.D. and J.C. Malechek. 1984. Diet selection by domestic goats in relation to blackbrush twig chemistry. J. Appl. Ecol. 21:831-837.
Provenza, F.D., E.A. Burritt, T.P. Clausen, J.P. Bryant, P.B. Reichardt, and R.A. Distel. 1990. Conditioned flavor aversion: a mechanism for goats to avoid condensed tannins in blackbrush. Amer. Nat. 136:810-828.

Ralphs, M.H. and F.D. Provenza. 1999. Conditioned food aversions: principles and practices, with special reference to social facilitation. Proc. Nutr. Soc. 58:813-820.

Ralphs, M.H., M.M. Kothman, and L.B. Merrill. 1986. Cattle and sheep diets under short-duration grazing. J. Range Manage. 39:217-223.

Santucci, P.M. and O. Maestrini. 1985. Body conditions of dairy goats in extensive systems of production: method of estimation. Ann. Zootech. 34:473-474.

SAS. 1990. SAS procedure users guide version 6. Third edition. SAS Institute Inc., Cary, N.C., USA.

Severson, K.H. and L.F. Debano. 1991. Influence of Spanish goats on vegetation and soils in Arizona chaparral. J. Range Manage. 44:111-117.

Sparks, D.L. and J.C. Malechek. 1968. Estimating percentage dry weight in diets using a microscopic technique. J. Range Manage. 21:264-265.

Steel, R.G. and J.H. Torrie. 1980. Principles and procedures of statistics. Second Edition. McGraw-Hill Book Co., New York, N.Y.

Tabosa, I.M., J.C.D. Souza, D.L. Graca, J.M. Barbosa, R.N. Almeida, and F. RietCorrea. 2000. Neuronal vacuolation of the trigeminal nuclei in goats caused by ingestion of Prosopis juliflora pods (Mesquite beans). Vet. Human Toxicol. 42:155-158.
Taylor, C.A. and M.M. Kothmann. 1990. Diet composition of Angora goats in a shortduration grazing system. J. Range Manage. 43:123-126.

Taylor, C.A., M.M. Kothmann, L.B. Merrill, and D. Elledge. 1980. Diet selection by cattle under high-intensity, low frequency, short duration, and Merrill grazing systems. J. Range Manage. 33:428-434.

Unanian, M.D.S. and E.D.E. Feliciano-Silva. 1984. Trace elements deficiency: Association with early abortion in goats. Int. Goat and Sheep Res. 2:129-134.

Walker, J.W., S.L. Kronberg, S.L. AlRowaily, and N.E. West. 1994. Comparison of sheep and goat preference for leafy spurge. J. Range Manage. 47:429-434.

Warren, L.E., D.N. Ueckert, and J.M. Shelton. 1984a. Comparative diets of Rambouillet, Barbado, and Karakul sheep and Spanish and Angora goats. J. Range Manage 37:172-180.

Warren, L.E., D.N. Ueckert, J.M. Shelton, and A.D. Chamrad. 1984b. Spanish goat diet on mixed-brush range-land in the south Texas plains. J. Range Manage. 37:340 $\neq 342$.

Wentzel, D. 1982. Non-infection abortion in Angora goats. In: Proc. III International Conference on Goat Production and Disease. Univ. Arizona, Tucson, Ariz.. pp 155-161.

White, S.M., B.L. Welch, and J.T. Flinders. 1982. Monoterpenoid content of pigmy rabbit stomach ingesta. J. Range Manage. 35:107-109. 